\title{
New genus of Cricetodontinae (Rodentia: Cricetidae) from the Late Miocene of Kazakhstan
}

\author{
Vladimir S. Zazhigin \\ ABSTRACT. The new genus Rhinocerodon gen. n., and three new species $R$. pauli sp. n., R. seletyensis \\ sp. n., and $R$. irtyshensis sp. n. are described from the Late Miocene of Kazakhstan. These forms represent \\ a new group of peculiar lophodont hamsters, Rhinocerodontini trib. $\mathbf{n}$.
}

KEY-WORDS: Rhinocerodon gen. n., Cricetodontinae, Late Miocene, Kazakhstan.

Vladimir Zazhigin [zazhigin@ginras.ru], Geological Institute of the Russian Academy of Sciences, Pyzhevsky per., 7, Moscow 119017, Russia.

\section{Новый род Cricetodontinae (Rodentia: Cricetidae) из позднего миоцена Казахстана}

\begin{abstract}
В.C. Зажигин
РЕЗЮМЕ. Rhinocerodon gen. n. описан из позднего миоцена Казахстана. Новый род представлен тремя видами ( $R$. pauli sp. n., $R$. seletyensis sp. n. и $R$. irtyshensis sp. n.) из трех разновозрастных местонахождений (MN12, MN13, MN13/14). R. pauli sp. n. и $R$. irtyshensis sp. n. принадлежат одной филетической линии. В составе подсемействе Cricetodontinae выделена особая триба лофодонтных хомяков, Rhinocerodontini trib. $\mathbf{n}$.
\end{abstract}

КЛЮЧЕВЫЕ СЛОВА: Rhinocerodon gen .n., Cricetodontinae, поздний миоцен, Казахстан.

\section{Introduction}

The history of hamsters of the subfamily Cricetodontinae is well studied based on the fossil assemblages of Europe and Asia Minor (Mein \& Freudenthal, 1971; Bruijn et al., 1993, Bruijn \& Ünay, 1996, and others). The fossil record of this group to the east of the Urals is much less detailed. Two species of the genus Tsaganocricetus Topachevsky et Skorik, 1988 [=Gobicricetodon Qiu, 1996] were described both from the Miocene of Kazakhstan (Topachevsky \& Skorik, 1988; Bendukidze, 1993) and from China (Qiu, 1996).

Remains of the new genus of Cricetodontinae were found in several Neogene localities of Kazakhstan in the south of the West Siberian Plain. In the locality Gusinyi Perelet in the suburbs of the city of Pavlodar the remains of the new genus come from two beds of different age. The older one is confined to the fossiliferous lens in the deposits of the Pavlodar Formation. This site, Pavlodar 1A (MN12), yielded the majority of mammal remains of the Pavlodar Complex. The material of the new genus is known from this locality since 1963 based on the collection of the present author and one of P.F. Savinov (AlmaAta). Because the Savinov's collection was more representative, we decided that description of the taxon should be presented by P.F. Savinov. Unfortunately, before his death Pavel Savinov could only mention the genus as Rhinocerodon gen. n. (Savinov, 1988: 29), a nomen nudum. In the subsequent list of mammals of the Pavlo- dar Complex this form was cited by me as Ruscinomyinae gen. n. (Zazhigin \& Zykin, 1984: 31) to prevent a coining of a new generic name before Savinov. Recently L.A. Tyutkova (2003: 219) in her list of the Pavlodar mammal fauna gave a new name, Rhinoceromys $(=$ Rhinocerodon Savinov, 1988) savinovi gen. et sp. n. This publication does not mention a holotype and place where the collection is housed. Therefore, according to the ICZN Article 16.4 the latter name is unavailable. The present publication validates the name proposed by Savinov.

The second fossiliferous bed (the locality Pavlodar 1B) of Gusinyi Perelet is associated with grey crossbedded sand of the Rytovo Formation overlying the red clay of the Pavlodar Formation. Small mammal fauna of the Pavlodar 1B belongs to the Cherlak Complex, which broadly corresponds to the Pontian localities of Ukraine. Because the position of the Miocene-Pliocene boundary in the continental deposits is so far ambiguous, the fauna of the Cherlak Complex is dated here in the range of the terminal Miocene or the basal Pliocene (MN13/MN14).

The third locality with remains of the new genus is Selety 1 A situated at the Selety River, $4 \mathrm{~km}$ upstream the Ilyinka village. Fossil remains originate from the deposits of the Late Miocene Kedey Formation. The association of small mammals (Lophocricetus vinogradovi Savinov, 1970 and Paranourosorex seletiensis Storch et Zazhigin, 1996) allows to date this site as the lower part of MN13. 
Each of the above mentioned localities yielded a separate species of the new genus. Materials are housed in the collection of the Geological Institute of the Russian Academy of Sciences (abbreviated GIN), Moscow.

\section{Systematic Paleontology}

Order Rodentia Bowdich, 1821

Family Cricetidae Fischer, 1817

Subfamily Cricetodontinae Stehlin et Shaub, 1951

Genus Rhinocerodon gen. n.

Type species. Rhinocerodon pauli sp. n., Upper Miocene of Kazakhstan (MN12).

Included species. $R$. seletyensis sp. n., Upper Miocene of Kazakhstan (lower MN13); R. irtyshensis sp. n., terminal Miocene or basal Pliocene of Kazakhstan (upper MN13 or lower MN14).

Etymology. From Greek Rhinoceros (rhino) and odus, odontos (tooth).

Diagnosis. Size medium. Molars brachyodont. Molar crowns relatively low, lophodont. Height of lophs and lophids equals to that of cones and conids. Enamel walls of crowns nearly uniformly thick, occlusal surface flat already in early wear stages. Mesocones and mesoconids absent. Lateral margins of $\mathrm{m} 1$ anteroconid labially (by anterolophulid) and lingually (by metalophid I) connected with protoconid and metaconid forming a sickle-shaped structure. Metaconid connected with protoconid by metalophid II. Upper part of the latter does not reach occlusal surface. In late wear stages metalophid II joins to the sickle-shaped structure and closes anterofossettid. Hypoconid small, strongly shifted anteriorly. Entoconid connected with hypoconid by a broad hypolophid. Posterolophid strong, and hypoconid and entolophid form a horse-shoe structure. In old specimens this structure closed into an irregular circle drawing a posterofossettid. Proto- and anterosinusids small or absent. Size of labial sinusid variable. Posterosinusid does not extend crown base. Mesosinusid deepest and longest. Mesosinusid together with labial sinusid divide $\mathrm{m} 1$ occlusal surface into two parts connected by narrow and long ectolophid. $\mathrm{m} 2$ and $\mathrm{m} 3$ lack lingual branches of anterolophid and have narrow and shallow posterosinusid. M1-2 have four roots. All cones of M1 and M2 strongly compressed, paracone and metacone notably pointed. In M1 relatively broad protocone branches connected to long and narrow anterocone and paracone. Anterosinus divided into nearly equal parts by anterolophule that does not reach occlusal surface. Posteroloph connected with metacone and hypocone. Metaloph I and anterior branch of hypocone connected with endoloph forming a closed field with large posterofossette inside. Endoloph connected with posterior part of paracone and not linked with protocone. Endo-, meso-, and anterosinuses of M1 broad and deep. M2 paracone connected with anterocone and endoloph. M2 protocone relatively large, strongly compressed, occasionally linked with paracone or endoloph. Short endoloph connects to posterior structure identical to that of M1. Dentary deep, the masseter platform wide. Masseter crests strong, diverging at a blunt angle. Mental foramen placed below $\mathrm{m} 1$ anterior root at level of masseter platform anglular point.

Differential diagnosis. Differs from all genera of the Cricetodontinae in the structure of $\mathrm{m} 1$ : the anteroconid is laterally connected with the protoconid and the metaconid, the hypoconid is strongly shifted anteriorly; and M1-M2: by endoloph-based formation of the closed structure comprising hypocone, posteroloph, and metacone.

Rhinocerodon pauli sp. n. Figs. 1; 2A, B, D, E, K.

Etymology. In honor of paleontologist Pavel Fedorovich Savinov.

Holotype. GIN 640/528, left m1.

Referred material. Fragmentary left dentary with $\mathrm{m} 2$ and $\mathrm{m} 3$; isolated teeth: five $\mathrm{M} 1$, four $\mathrm{M} 2$, four $\mathrm{m} 1$, three $\mathrm{m} 2$, and one m3. Collected by V.S. Zazhigin in 1963-1965, 1976, and 1980.

Type locality. Pavlodar 1A, Gusinyi Perelet, Pavlodar city, Kazakhstan.

Stratigraphic level. Pavlodar Formation, MN12, Upper Miocene.

Description. The basic molar characters coincide with the generic diagnosis given above. Individual variability is low. Of five available $\mathrm{m} 1$ the anterofossettid is absent in one specimen. The depth of the posterosinusid in all lower molars is less than that of the mesosinusid. The posterosinusid of $\mathrm{m} 3$ is likely obliterates very early. Size of the hyposinusid in $\mathrm{m} 1$ is variable. Labial branch of the anterolophid in $\mathrm{m} 2$ and $\mathrm{m} 3$ is short. The lingual margins of the posterolophid and entoconid in $\mathrm{m} 2$ and $\mathrm{m} 3$ are very close to each other, the protoconid is relatively small. The M1 anterocone has a weak lingual bulge that disappears with early wear. Four of five M1 have mesostyles and two M1 have endostyles. Of the four M1 one molar does not show a link of the protocone and metacone.

Measurements. Length $\times$ width of crowns are measured in mm at occlusal surfaces: $\mathrm{m} 1: 2.30 \times 1.25(\mathrm{GIN}$ $640 / 528$, holotype); $2.30 \times 1.35$ (GIN 640/530); $2.30 \times$ 1.25 (GIN 640/531); $2.30 \times 1.25($ GIN 640/532); $2.35 \times$ $1.30(\mathrm{GIN} 640 / 533) ; \mathrm{m} 2: 1.40 \times 1.00($ GIN 640/536); $1.95 \times 1.35($ GIN 640/535); $1.95 \times 1.55$ (GIN 640/534); $1.80 \times 1.25(\mathrm{GIN} 640 / 529) ; \mathrm{m} 3: 1.60 \times 1.20(\mathrm{GIN} 640 /$ $529) ; 1.60 \times 1.30($ GIN 640/537); M1: $2.5 \times-(\mathrm{GIN}$ $640 / 538) ; 2.40 \times 1.50($ GIN $640 / 539) ; 2.70 \times 1.35(\mathrm{GIN}$ $640 / 540) ; 2.50 \times 1.35($ GIN $640 / 541) ; 2.60 \times 1.50(\mathrm{GIN}$ $640 / 542)$; M2: $1.65 \times 1.30($ GIN 640/543); $1.75 \times 1.40$ $($ GIN 640/544); $1.70 \times 1.60($ GIN 640/545); $1.65 \times 1.25$ (GIN 640/546;

Maximal crown height: m1, 1.05 (GIN 640/528, holotype); m2, 1.50 (GIN 640/536, unworn); M1, 1.30 (GIN 640/540); M2, 1.35 (GIN 640/544).

Remarks. In 1982 I collected the single $\mathrm{m} 3$ of Rhinocerodon sp. in deposits of the lower Maeotian of Ukraine, the locality Bereznegovatoe (see Gozhik \& 

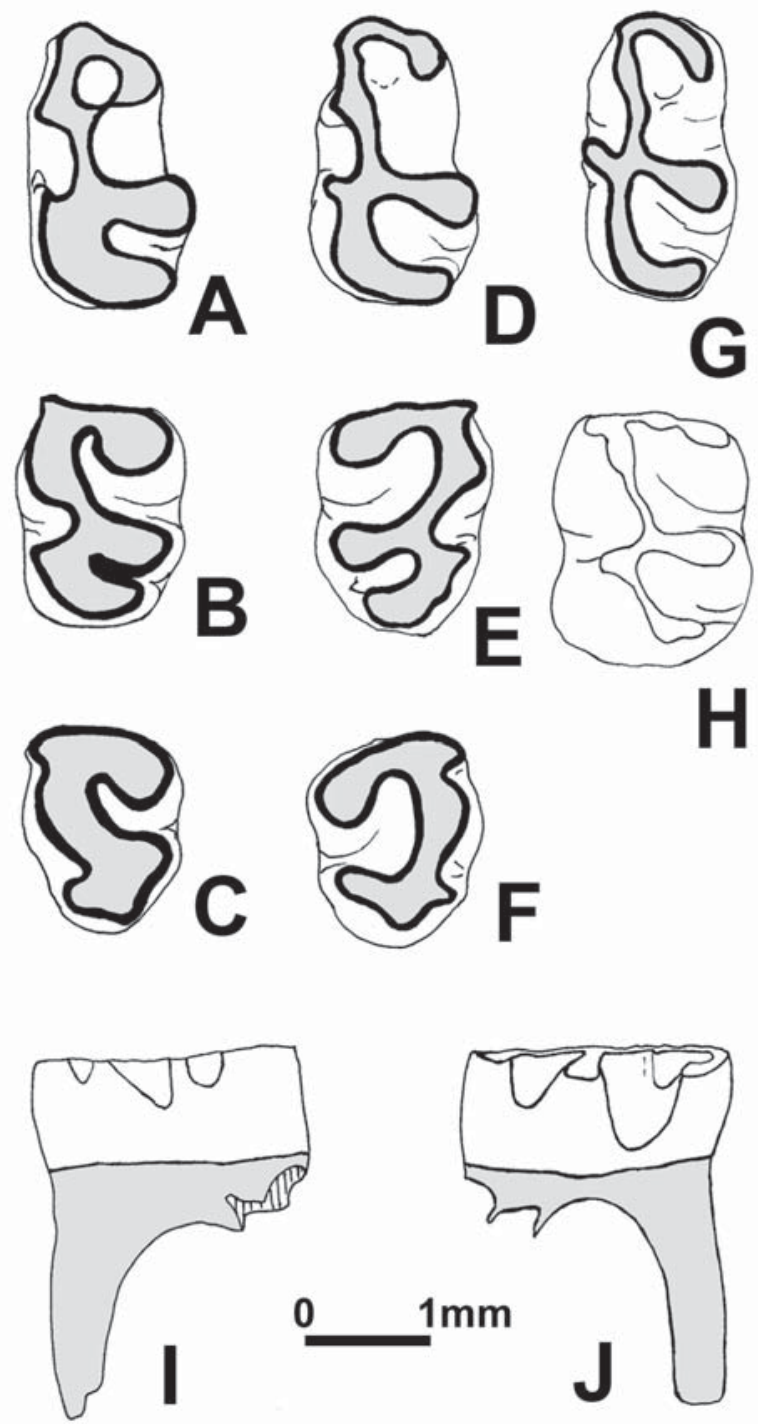

Figure 1. Molars of Rhinocerodon pauli sp. n. in occlusal (A$\mathrm{H})$, labial (I), and lingual (J) views. Pavlodar 1A locality, Gusinyi Perelet, Pavlodar city, Kazakhstan; Pavlodar Formation, MN12, Upper Miocene.

A - GIN 640/530, left m1; B - GIN 640/529, left m2; C - GIN 640/529, left m3; D - GIN 640/531, left m1; E - GIN 640/535, right $\mathrm{m} 2$; F — GIN 640/537, right $\mathrm{m} 3$; G, I and J — GIN 640/528, left $\mathrm{m} 1$, holotype; H - GIN 640/536, left m2, unworn.

Prisyazhnyuk, 1978). This specimen $(1.5 \times 1.20 \mathrm{~mm})$ lacks posterosinusid, whereas the posterolophid is not worn. In size and structure it is very similar to the $\mathrm{m} 3$ GIN 640/537 (Pavlodar 1A) with the very weak and small posterolophid. It is possible that the Pavlodarian form can have $\mathrm{m} 3$ without posterosinusid as well.

Distribution. The type locality.

Rhinocerodon seletyensis $\mathbf{s p .} \mathbf{n}$.

Fig. 2C, H, I.

Etymology. From Selety River.

Holotype. GIN 951/1033, fragmentary left dentary with $\mathrm{m} 1-\mathrm{m} 3$.
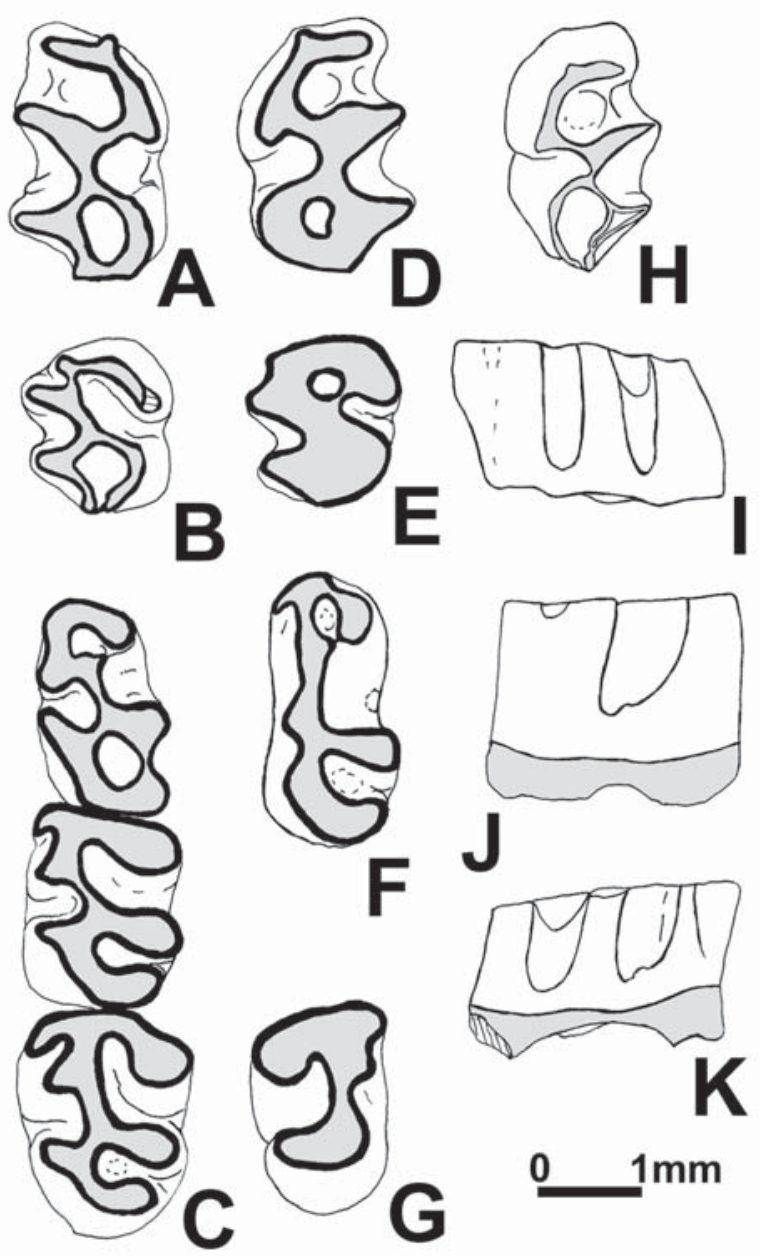

Figure 2. Molars of Rhinocerodon pauli sp. n. (A, B, D, E, K; Pavlodar 1A locality, Gusinyi Perelet, Pavlodar city; Pavlodar Formation, MN12, Upper Miocene), R. seletyensis sp. n. (C, H, I; Selety 1A locality, Selety River; Kedey Formation, lower MN13, Upper Miocene) and R. irtyshensis sp. n. (F, G, J; Pavlodar 1B locality, Gusinyi Perelet, Pavlodar city; Rytovo Formation, terminal Miocene [MN13] or basal Pliocene [MN14]) from Kazakhstan in occlusal (A-H) and lingual (I$\mathrm{K})$ views.

A and $\mathrm{K}$ - GIN 640/542, right M1; B - GIN 640/546, right M2; C GIN 951/1033, left m1-3, holotype; D — GIN 640/539, left M1; E GIN 640/544, right M2; F and J - GIN 640/3015, left m1, holotype; G - GIN 640/3016, right m3; H and I — GIN 951/1036, left M1.

Referred material. Fragmentary right dentary with $\mathrm{m} 2$ and alveoli of $\mathrm{m} 1$ and $\mathrm{m} 3$; isolated teeth: two M1, fragment of $\mathrm{m} 1$ with preserved anteroconid, protoconid, and metaconid. Collected by V.S. Zazhigin in 1980, and by V.S. Zykin in 1983.

Type locality. Selety 1A, Selety River, Kazakhstan.

Stratigraphic level.Kedey Formation, lower MN13, Upper Miocene.

Description. Structure and size of $\mathrm{m} 1$ and $\mathrm{M} 1$ as in the type species. Both M1 specimens lack styles. m2 and, particularly, $\mathrm{m} 3$ are relatively large compared to $\mathrm{m} 1$. Labial branches of anterolophid in $\mathrm{m} 2$ and $\mathrm{m} 3$ are well developed. The sinusids of $\mathrm{m} 2$ and $\mathrm{m} 3$ are well 
developed and present till late wear stages. The structure of the dentary as given in the generic diagnosis.

Measurements. The length of the toothrow (m1-m3) in GIN 951/1033, holotype is 6.05. Length $\times$ width of molars in GIN 951/1033, holotype: $\mathrm{m} 1: 2.20 \times 1.35$; m2: $2.10 \times 1.55 ; \mathrm{m} 3: 1.95 \times 1.60$. Length and width of other molars: $\mathrm{m} 2$ : $2.00 \times 1.50($ GIN 951/1034); M1: $2.40 \times$ 1.35 (GIN 951/1035); $2.45 \times 1.25$ (GIN 951/1036).

Comparison. The new species is distinct from $R$. pauli sp. n. in larger $\mathrm{m} 2$ and, particularly, $\mathrm{m} 3$; in more developed branches of the anterolophid and deeper sinusids of these teeth.

Distribution. The type locality.

\section{Rhinocerodon irtyshensis $\mathbf{s p .} \mathbf{n}$.}

Fig. 2F, G, J.

Etymology. After Irtysh River.

Holotype. GIN 640/3015, left m1.

Referred material. One m3. Material collected by V.S. Zazhigin in 1976 (the holotype) and 1980.

Type locality. Pavlodar 1B, Gusinyi Perelet, Pavlodar city, Kazakhstan.

Stratigraphic level. Rytovo Formation, terminal Miocene (MN13) or basal Pliocene (MN14).

Description. Molar crowns are relatively narrow. The $\mathrm{m} 1$ protoconid, anteroconid, and metaconid are placed very close to each other; the metalophid early joins the protoconid and forms a shallow anterofossettid. The anteroconid shows a labial branch that disappears early with the wear. The entoconid broadly connects with the hypoconid and with the broad and long posterolophid. The hypoconid is shallow, fuses with the ectolophid at early wear stages. The posterosinusid is relatively broad but shallow. The posterofossettid is formed at early wear stages but later than the anterofossettid. The mesosinusid is broad and deep. Small mesostylid and ectostylid are present. The anterosinusid is small and shallow. The m3 lacks the posterofossettid. The labial sinusid and anterosinusid are strongly reduced. The mesosinusid is broad and deep.

Measurements. Length and width: $\mathrm{m} 1: 2.70 \times 1.20$ (GIN 640/3015, holotype); m3: 1.70 x 1.45 (GIN 640/ 3016). Maximal crown height in GIN 640/3015, holotype is 1.60 ; in $\mathrm{m} 3-1.50$.

Comparison. The new species differs from $R$. pauli sp. n. and $R$. seletyensis sp. n. in the presence of the labial branch of anterolophid, in narrow and long $\mathrm{m} 1$, and in early developed fossettids by reduction of the labial sinusid and anterosinusid.

Distribution. The type locality.

\section{Discussion}

The assignment of the genus Rhinocerodon gen. $\mathbf{n}$. into Cricetodontinae is based mainly on the lower molars structure. The dental trends studied for the fossil genus Deperetomys Mein et Freudenthal, 1971 (Bruijn et al., 1993) are helpful in elucidation of systematic position of many Miocene Cricetodontinae. They are likely developed in many lineages in parallel. These trends are manifested in Rhinocerodon gen. n. to the maximal extent. They include: 1) increase of the crests connecting cusps; 2) reduction of the posterior branch of the hypoconid; 3) reduction of the ectolophid; 4) development of the parallel fusion of crests of the protoconid and metaconid with the anteroconid. The height of crests gets equal to that of cusps in lower and upper molars. The posterolophid completely fuses with hypoconid. The ectolophid is reduced, and lateral margins of the anteroconid connect with the protoconid and metaconid. Also reduced are the mesocone and mesoconid, lingual branches of the anteroloph in M2 and those of the anterolophid in $\mathrm{m} 2$ and $\mathrm{m} 3 . \mathrm{m} 2$ and $\mathrm{m} 3$ became similar to the molars of Hispanomys Mein et Freudenthal, 1971. M1 and M2 of Rhinocerodon gen. n. acquired characters that differ them from other Cricetodontinae.

Molar morphology and stratigraphic position of the species of Rhinocerodon gen. n. points to the presence of the two phyletic lineages. The oldest and youngest forms, $R$. pauli sp. n. and $R$. irtyshensis sp. n., likely belong to the same phyletic line. This is indicated by relatively narrow $\mathrm{m} 2$ and $\mathrm{m} 3$, reduced posterosinusids in these molars of the both species. $R$. seletyensis $\mathbf{s p .} \mathbf{n}$. represents another lineage. It is notably stratigraphically younger than $R$. pauli sp. n. but has more primitive characters, like stronger developed labial branches of anterolophid and posterosinusids in $\mathrm{m} 2$ and $\mathrm{m} 3$. The $\mathrm{m} 3$ of $R$. seletyensis sp. n. is larger than in R. pauli $\mathbf{s p .} \mathbf{n}$.

The specific structure of the m1, M1, M2, and dentary of Rhinocerodon gen. n. makes it distinct from all genera of the tribes of the Cricetodontinae. In my view, the genus level characters of Rhinocerodon gen. n., its species diversity, and the presence of several phyletic lineages suffice the erection of the new tribe Rhinocerodontini trib. nov.

The history of the tribe Rhinocerodontini trib. $\mathbf{n}$. is known for a relatively short interval spanning the Late Miocene to basal Pliocene. The known diversity of Cricetodontinae of Europe and Asia Minor gives no clues for the affinities of the Rhinocerodon gen. n. Likewise, no ancestral forms of the new genus are so far known in the Central Asia among the unpublished collections of Cricetodon Lartet, 1850, Tsaganocricetus, and Hispanomys stored in the Geological Institute RAS, Moscow. These materials reveal insufficiently the Miocene history of the Cricetodontini in Central Asia. In spite of the poorly known fossil record of the region, it is likely that the ancestry of Rhinocerodon gen. n. should be looked for in the faunas of the Middle Miocene of the Central Asia.

ACKNOWLEDGEMENTS. I thank A.S. Tesakov for the English translation and preparation of illustrations and A.V. Lopatin for discussion and helpful comments.

\section{References}

Bendukidze O.G. 1993. [Small mammals of the Miocene of South-Western Kazakhstan and Turgai]. Tbilisi: Metsniereba. 144 p. [in Russian]. 
Bruijn H. de, Fahlbuch V., Sarac G. \& Ünay E. 1993. Early Miocene rodent faunas from the eastern Mediterranean area. Part III. The genera Deperetomys and Cricetodon with discussion of the evolutionary history of the Cricetodontini // Proceedings Koninklijke Nederlandse Akademie van Wetenschappen, Series B. Vol.96. No.2. P.151-216.

Bruijn H. de \& Ünay E. 1996. On the evolutionary history of the Cricetodontini from Europe and Asia Minor and its bearing on the reconstruction of migrations and the continental biotope during the Neogene // Bernor R.L., Fahlbusch V. \& Mittmann H.W. (eds.). Evolution of Western Eurasian Neogene Mammals Faunas. New York: Columbia Press. P.227-234.

Gozhik P.F. \& Prisyazhnyuk V.A. 1978. [Fresh-water and land mollusks of the Miocene of the right-bank Ukraine]. Kiev: Naukova Dumka. 173 p. [in Russian].

Mein P. \& Freudenthal M. 1971. Une nouvelle classification des Cricetidae (Mammalia, Rodentia) du Tertiaire de l'Europe // Scripta Geologica. No.2. P.1-37.

Qiu Z.D. 1996. Middle Miocene micromammalian fauna from Tunggur, Nei Mongol. Beijing: Science Press. 216 p. [in Chinese with English summary]

Savinov P.F. 1988. [Change of faunistic complexes of small mammals in Neogene of Kazakhstan] // Materialy po Istorii Fauny i Flory Kazakhstana. T.10. P.12-33 [in Russian]. Topachevsky V.A. \& Skorik A.F. 1988. [New vole-toothed Cricetodontinae (Rodentia, Cricetidae) from Vallesian of Eurasia and some questions of suprageneric systematics of the subfamily] // Vestnik zoologii. No.5. P.37-45 [in Russian].

Tyutkova L.A. 2003. [Neogene rodents of the "Gusinyi Perelet" locality (Pavlodar, Kazakhstan)] // Averianov A.O. \& Abramson N.I. (eds.). [Systematics, Phylogeny and Paleontology of Small Mammals]. Sankt-Peterburg: Zoologicheskii Institut RAN. P.218-220 [in Russian with English summary].

Zazhigin V.S. \& Zykin V.S. 1984. [New data on the stratigraphy of Pliocene of the south of the West Siberian Plain] // Arkhipov S.A. (ed.). [Stratigraphy of the Boundary Deposits of the Neogene and Anthropogene of Siberia]. Novosibirsk: Institut Geologii i Geofiziki Sibirskogo Otdeleniya AN SSSR. P.29-53 [in Russian]. 